\title{
Human Donor Breast Milk Bank: What is on the horizon?
}

\author{
Uday P Devaskar* and Sudhir P Waghmare \\ Division of Neonatology, Department of Pediatrics, David Geffen School of Medicine at UCLA, Los Angeles, California, USA and \\ Shreeyash Electro Medicals, Pune, Maharashtra, India
}

*Corresponding author: Uday P Devaskar, Division of Neonatology, Department of Pediatrics, David Geffen School of Medicine at UCLA, Los Angeles, USA

\section{ARTICLE INFO}

Received: 櫘 September 14, 2020

Published: 幽 September 30, 2020

Citation: Uday P Devaskar, Sudhir P Waghmare. Human Donor Breast Milk Bank: What is on the horizon?. Biomed J Sci \& Tech Res 30(5)-2020. BJSTR. MS.ID.005015.

\section{ABSTRACT}

Abbreviations: BM: Breast Milk; DBM-Donor Breast Milk; DBMB-Donor Breast Milk Bank; EBM- Expressed Breast Milk; HTLV-Human T-cell Leukemia Virus; HBMP-Human Breast Milk Pasteurizer; IUGR- Intrauterine Growth Restriction; MBM-Mother's Breast Milk; NICU-Neonatal Intensive Care Unit; PDBM-Pasteurized Donor Breast Milk

\section{Introduction}

Mother's breast milk (MBM) is the Rolls Royce of all feeding option for all neonates [1-6]. However, MBM is not always available, insufficient or is not suitable. Under these conditions, pasteurized donor breast milk (PDBM) purchased from a donor breast milk bank (DBMB) is a better option than the preterm formula [1-6]. DBMB rely on mothers who have delivered a baby at full-term gestation and have been lactating for several weeks [7-10]. Generally, milk from four to six mothers is pooled. Sterifeed (England) or HSC (France) pasteurizers have been used for several decades. These devices are large, expensive, require special electrical and water connections, need a large amount of water which is not recycled and an ongoing supply of disposable plastic bottles. Use of these devices require special training. To be cost effective they need a large volume of milk during each cycle. Therefore, the use of these devices has remained limited to DBMB in developed countries or larger hospitals in big cities in the developing countries.

Recently we have developed a compact, portable, user-friendly breast milk pasteurizer (BMP) capable of pasteurizing 5 to $500 \mathrm{ml}$ of expressed breast milk (EBM) during each cycle using the principle of Holder pasteurization [11]. This device, named Kimie, does not require special water plumbing, re-cycles water and is inexpensive. It is eco-friendly and automated using modern microprocessor technology. It requires only $4500 \mathrm{ml}$ of water which is recycled. To be eco-friendly, for easy cleaning and to be cost-effective, it uses grade 304 stainless-steel cylinders instead of the disposable plastic bottles [12]. In the food industry, the regulating agencies prefer to use stainless-steel for heating, cooling or drying because it prevents any chemical reaction between the food and the container [12]. Kimie has received the European Certificate of compliance (no 1810170911101) for a Human Milk Pasteurizer and met Standards EN 6060-1, EN 60601-1-2, and EN 60601-1-6 to demonstrate conformity. In the USA, any BM pasteurizer does not require federal drug administration approval since it is considered a catering device. Kimie can be imported to the USA under commodity code number 84198998.

There is an increasing trend to initiate enteral nutrition as early as 6 hours of life [13-17]. Baby's own mother's expressed breast milk (EBM) is the best feeding option. The overarching goal is to reach full enteral EBM feeding in the shortest possible time [1-17]. However, when Mother's EBM milk is not available, insufficient or not suitable, supplementation with PDBM is a common practice [1- 
6]. Kimie can be easily installed in the in-hospital setting. A physician nurse or both can approach mothers who deliver premature babies in the immediate post-partum period. Information regarding their medical and lifestyle risk factors, and prenatal serum syphilis, HIV, Hepatitis B and C, HTLV is readily available from the pre-natal records. The NICU staff can easily educate these mothers regarding the need for expressing milk, the importance of breast hygiene, proper collection and storage of EBM. Mothers can express BM in the hospital under supervision of a nurse or a lactation specialist. These mothers can be requested, as needed, to express milk more than what their baby requires, With the availability of Kimie, it will be easy to give PDBM obtained from another mother who had a premature baby a few days or weeks ago, and is now able to produce extra milk than what her baby requires.

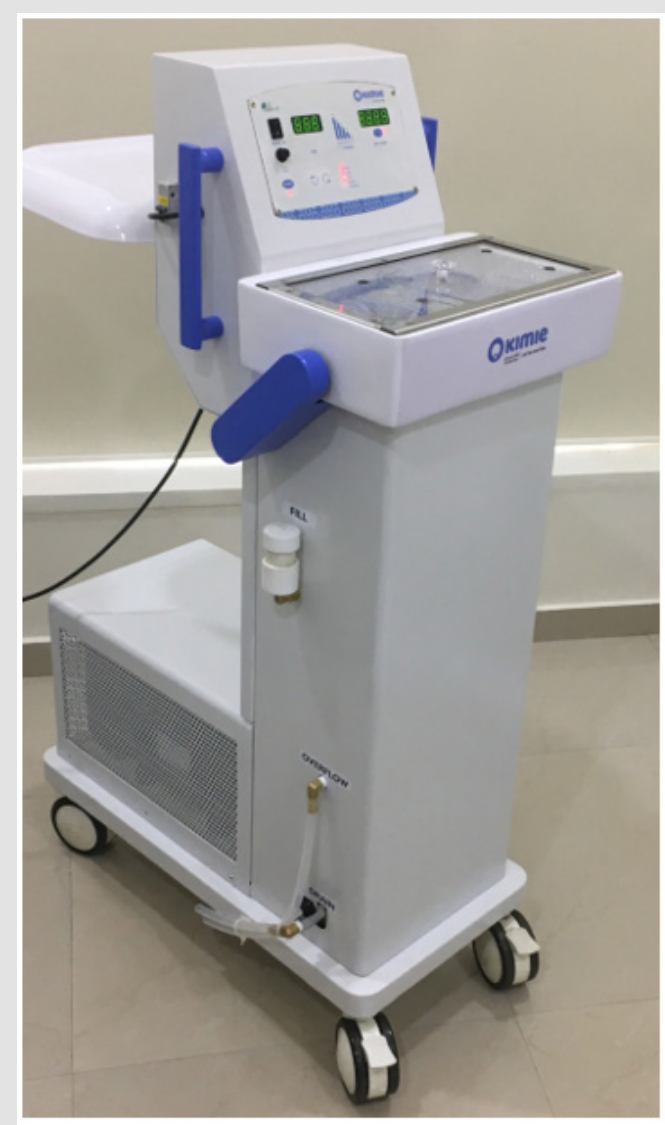

Figure 1: Kimie: The Bird's Eye Views.

The DBM from the preterm mother can be pasteurized and stored frozen. This approach will decrease the need for DBM obtained from mothers who had a baby at full term gestation. Use of preterm milk is better since it has a higher content of protein, fat, aminoacids, lysozymes, calcium and sodium [18-21]. Clinical studies to establish the validity of above stated approach using devices like Kimie seem warranted. Transmission of cytomegalovirus (CMV) from the use of natural mother's raw BM to her baby, particularly the very preterm, has been established [22-26] In a recent study an association between postnatal CMV infection and adverse outcomes was confirmed [27]. CMV is reactivated even in healthy immunocompetent seropositive women during pregnancy and lactation [22-26]. The rate of CMV reactivation during the first three months is almost $100 \%$ [22-26]. In a prospective study, 73 out of 76 (96\%) seropositive mothers shed CMV into BM when the baby was delivered at $<32$ weeks of gestational age (GA) or weighed $<$ 1500 grams [22-26].

When fed raw untreated BM, the transmission of CMV occurred in 33 out of 90 (37\%) infants by three months of corrected GA [2226]. However, a lower incidence has been reported when BM was pre-treated with Holder pasteurization. While pasteurization of the BM completely eliminates CMV [22-26], it has not been feasible to pasteurize own mother's EBM since the existing pasteurizers were not readily available. With the availability of Kimie it should be easy to pasteurize the natural mother's BM to eliminate CMV before it is given to the at-risk very premature infant.

In the absence of prophylactic pharmacotherapy, breastfeeding accounts for half of mother to-child transmission of HIV-1 [2833]. Co-infections in BM with CMV are associated with increased postnatal maternal to child transmission of HIV-1. However, BM remains crucial for infant survival in countries with limited resources. Therefore, in HIV-1 positive women, the elimination of CMV and HIV-1 virus by pasteurizing mother's BM prior to its consumption will abolish vertical CMV and HIV-1 transmission. With the availability of Kimie it should be feasible to do so.

A few examples of primary immunodeficiencies (PIDs) with T-cell lymphopenia include severe Combined Immunodeficiency (SCID), 22q11 deletion syndrome, (DiGeorge), CHARGE syndrome, VACTERL association and ataxia telangiectasia [34]. The clinical course of SCID is well understood and life-saving treatments including hematopoietic stem transplantation (HSC) have become available [34]. Infants with SCID are at a high risk of developing CMV and other infections. CMV is transmitted by oral secretion or mother's BM. The acquisition of CMV negatively affects the success of HSCT [34]. Therefore, no breast feeding or use of PDBM is recommended [34]. With the availability of Kimie it should be easy to pasteurize the natural mother's EBM prior to feeding her infant. At UCLA hospital one infant was diagnosed with SCID at nine days of age through the newborn metabolic screening program. His mother's blood had high levels of IgG antibodies against CMV. Staring at nine days of age he has been receiving his own mother's EBM that has been pasteurized daily using Kimie. He is five months old, has remained CMV negative while awaiting stem cell bone marrow transplant.

In summary, with the availability of devices like Kimie we envision mushrooming of in-hospital installed donor breast milk banks all over the world. This approach will help in further improving the health of neonates, premature and full term alike. 


\section{References}

1. Picaud JC, Buffin R (2017) Human Milk-Treatment and Quality of Banked Human Milk. Clin Perinatol 44(1): 95-119.

2. Quigley M, McGuire W (2014) Formula versus donor breast milk for feeding preterm or low birth weight infants. Cochrane Database Syst Rev (4): CD002971.

3. Breastfeeding and the Use of Human Milk (2012) Section on breastfeeding. Pediatrics 129(3): e827-e841.

4. Arslanoglu S, Corpeleijn W, Moro G, Braegger C, Campoy C, et al. (2013) Donor human milk for preterm infants: current evidence and research directions. J Pediatr Gastroenterol Nutr 57(4): 535-542.

5. Agostoni C, Buonocore G, Carnielli VP, M De Curtis, D Darmaun, et al. (2010) Enteral nutrient supply for preterm infants: commentary from the European Society of Paediatric Gastroenterology, Hepatology and Nutrition Committee on Nutrition. J Pediatr Gastroenterol Nutr 50(1) 85-91.

6. Arslanoglu S, Moro GE, Bellu R, Turoli D, Giuseppe De Nisi, et al. (2013) Presence of human milk bank is associated with elevated rate of exclusive breastfeeding in VLBW infants. J Perinat Med 41(2): 129-131.

7. (2018) Human Milk Banking Association of North America 2018, Guidelines for the Establishment and Operation of a Donor Human Milk Bank. Fort Worth, TX: Human Milk Banking Association of North America.

8. Jones F (2019) Best Practice for Expressing, Storing and Handling Human Milk in Hospitals, Homes, and Child Care Settings. Fort Worth, TX: Human Milk Banking Association of North America.

9. Human Milk Bank Association of North America (2013) Guidelines for the establishment and operation of a donor Human Milk Bank.

10. Hurst NM, Myatt A, Schanler RJ (1998) Growth and development of a hospital-based lactation program and mother's own milk bank. J Obstet Gynecol Neonatal Nurs 27(5): 503-510.

11. Sudhir Waghmare, Akshay Kharche, Shilpa U Kalane, Vishakha Haridas, Sampada Patwardhan and Uday P. Devaskar Research Square. https/doi. org/1021203/rs3.rs-67152/v1.

12. www.marlinware.com

13. Flidel-Rimon O, Friedman S, Lev E, A Juster-Reicher, M Amitay, et al. (2004) Early enteral feeding and nosocomial sepsis in very low birthweight infants. Arch Dis Child Fetal Neonatal Ed 89(4): F289-F292.

14. Hamilton E, Massey C, Ross J, Taylor S (2014) Early enteral feeding in very low birth weight infants. Early Hum Dev 90(5): 227-30.

15. Lenhartova N, Matasova K, Lasabova Z, Javorka K, Calkovska A (2017) Impact of early aggressive nutrition on retinal development in premature infants. Physio Res 66(2): S215-S226.

16. Tewari VV, Dubey SK, Kumar R, Vardhan S, CM Sreedhar, et al. (2018) Early versus Late Enteral Feeding in Preterm Intrauterine Growth Restricted Neonates with Antenatal Doppler Abnormalities: An OpenLabel Randomized Trial. J Trop Pediatr 64(1): 4-14.

17. Dutta S, Singh B, Chessell L, Wilson J, Janes M, et al. (2015) Guidelines for feeding very low birth weight infants. Nutrients 7(1): 423-442.

18. Lonnerdal B (2017) Bioactive proteins in human milk-potential benefits for preterm infants. Clin Perinatol 44(1): 179-191.
19. Lonnerdal B (2003) Nutritional and phyiologic significance of human milk proteins. Am J Clin Nutr 77(6): 1537S-1543S

20. Lonnerdal B (2010) Bioactive proteins in human milk: Mechanisms of action. J Pediatr 156 (suppl2): S26-S30

21. Molinari CE, Casadio YS, Hartmann BT, Livk A, Bringans S, et al. (2012) Proteome mapping of human skim milk proteins in term and preterm milk. J Proteome Res 11(3): 1696-1714.

22. Hamprecht K, Goelz R (2017) Postnatal cytomegalovims infection through human milk in preterm infants' transmission, clinical presentation, and prevention. Clin Perinatal 44(1): 121-130.

23. Bialas KM, Swamy GK, Permar SR (2015) Perinatal cytomegalovirus and varicella zoster virus infections: epidemiology, prevention, and treatment. Clin Perinatol 42(1): 61-75.

24. Wood AM, Hughes BL (2018) Detection and Prevention of Perinata Infection: Cytomegalovirus and Zika Virus. Clin Perinatol 45(2): 307323.

25. Bardanzellu F, Fanos V, Reali A (2019) Human Breast Milk-acquired Cytomegalovirus Infection: Certainties, Doubts and Perspectives. Current pediatric reviews 15(1): 30-41.

26. Schleiss MR (2020) Breast Milk-Acquired Cytomegalovirus in Premature Infants: Uncertain Consequences and Unsolved Biological Questions. JAMA Pediatr 174(2): 121-123.

27. Weimer KED, Kelly MS, Permar SR, Clark RH, Greenberg RG (2020) Association of Adverse Hearing, Growth, and Discharge Age Outcomes with Postnatal Cytomegalovirus Infection in Infants with Very Low Birth Weight. JAMA Pediatr 174(2): 133-140.

28. Viljoen J, Tuaillon E, Nagot N, Danaviah S, Peries M, et al. (2015) Cytomegalovirus, and possibly Epstein-Barr virus, shedding in breast milk is associated with HIV-1 transmission by breastfeeding. AIDS 29(2): 145-153.

29. Slyker J, Farquhar C, Atkinson C, Asbjornsdottir K, Alison C Roxby, et al. (2014) Compartmentalized cytomegalovirus replication and transmission in the setting of maternal HIV-1 infection. Clin Infect Dis 58(4): 564-572.

30. Kovacs A, Schluchter M, Easley K, G Demmler, W Shearer, et al. (1999) Cytomegalovirus infection and HIV-I disease progression in infants born to HIV-I-infected women: Pediatric Pulmonary and Cardiovascular Complications of Vertically Transmitted HIV Infection Study Group. N Engl J Med 341(2): 77-84.

31. Nigro G, Krzysztofiak A, Gattinara GC, T Mango, M Mazzocco, et al. (1996) Rapid progression of HIV disease in children with cytomegalovirus DNAemia. AIDS 10(10): 1127-1133.

32. Slyker JA, Lohman-Payne BL, Rowland-Jones SL, Phelgona Otieno, Elizabeth Maleche-Obimbo, et al. (2009) The detection of cytomegalovirus DNA in maternal plasma is associated with mortality in HIV-I-infected women and their infants. AIDS 23(1): 117-124.

33. Slyker JA, Lohman-Payne BL, John-Stewart GC, Elizabeth MalecheObimbo, Sandra Emery, et al. (2009) Acute cytomegalovirus infection in Kenyan HIV-infected infants. Aids 23(16): 2173-2181.

34. Verbsky J, Routes J (2014) Screening for and treatments of congenital immunodeficiency diseases. Clin Perinatol 41(4): 1001-1015. 
ISSN: 2574-1241

DOI: $10.26717 /$ BJSTR.2020.30.005015

Uday P Devaskar. Biomed J Sci \& Tech Res

(c) (P) This work is licensed under Creative

Submission Link: https://biomedres.us/submit-manuscript.php

$\begin{array}{ll}\text { BIOMEDICAL } & \text { Assets of Publishing with us } \\ \text { RESEARCHES } & \text { Global archiving of articles } \\ & \text { - Immediate, unrestricted online access } \\ & \text { - Rigorous Peer Review Process } \\ \end{array}$

